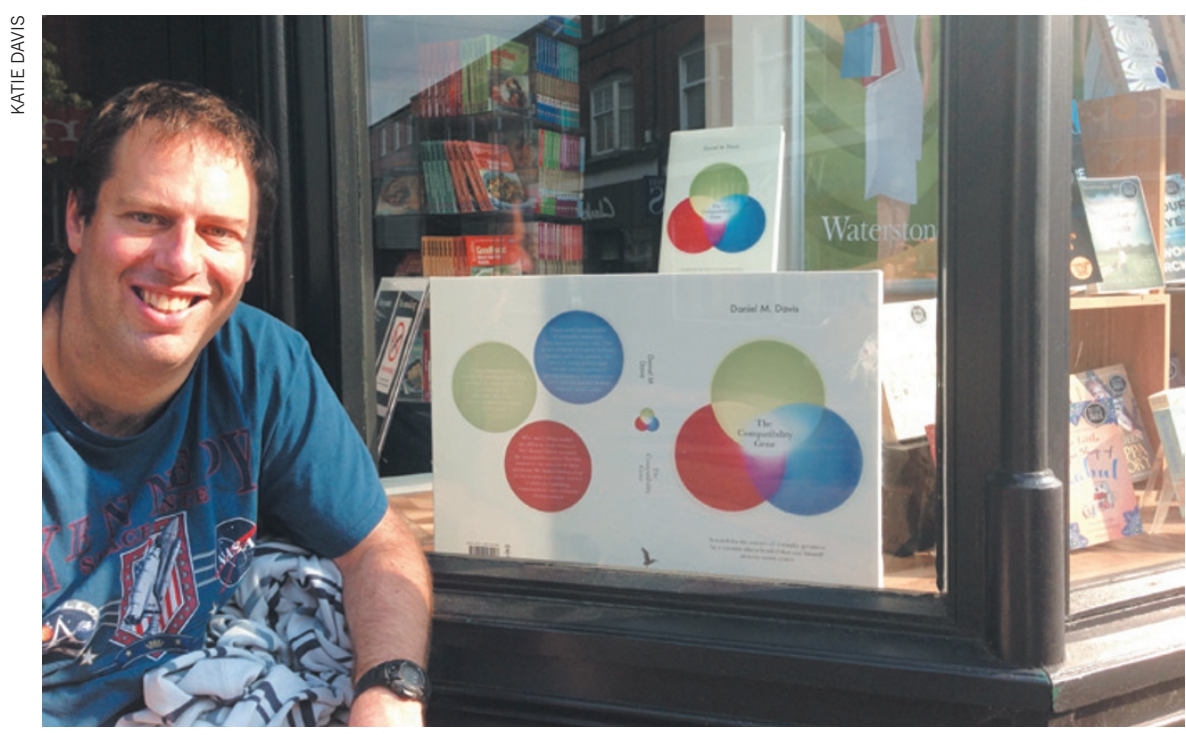

Daniel Davis wrote about differences in genes of the human immune system, a topic that had received little attention in the popular-science market.

As a big project with multiple moving parts, writing a book can be all-consuming. Davis says that it is almost impossible to be a brilliant teacher, researcher and author all at the same time. While writing, he kept up his lab but did not teach. Most scientist-authors write books during a sabbatical or on leave while teaching is not in session. Pepperberg wrote The Alex Studies in three-hour blocks from 9 a.m. to noon each day, and spent the rest of her 13-hour workdays in her laboratory. The writing, she says, took the place of teaching and committee work during that time.

Once a book is published, authors have to get involved in marketing. They need to be able to talk about it to an average reader, and might be asked to do interviews on radio or television and give talks. Marketing can be gruelling. "There's just not enough hours in the day and not enough ATP in the body," says Haskell, who is currently taking a year of unpaid leave from teaching to promote his current book and to prepare his next one. For this year, his income comes from his book earnings and from fees for book-related speaking engagements.

Because of these demands, most scientistauthors advise other academic researchers not to start writing a book before they earn tenure. "I think it's a mistake until you're comfortable establishing a lab and getting grants," says Pinker. But Davis says that people with an enduring passion for book writing should just go ahead and dive in when offered the opportunity - or they might miss the chance.

\section{MEASURING SUCCESS}

Predicting which books will succeed and which will fail is never easy. Even if a book gets critical acclaim, there is no guarantee that the public will embrace it. Haskell recognizes that he is one of the lucky ones: his The Forest Unseen was a finalist for the 2013
Pulitzer Prize for General Non-Fiction, and won this year's US National Academy of Sciences book award. It has also sold well, says Haskell, both through mainstream booksellers and as a result of being adopted for use in academic courses.

But regardless of commercial success, the mental energy that goes into book writing can enrich a scientific career. Pinker sees writing as an extension of his academic research; it is like doing theoretical science with an audience. Davis has taken advantage of the time he spent thinking about 60 years of research and interviewing other scientists: since writing his book, he has used the ideas he came across to pull out new themes for his group's research. Seeing the big picture revealed new ways to focus on important questions in the field. For example, his laboratory is now looking at how different individuals' immune systems respond to various types of diseased cells.

Long's book has raised his public profile and led him to two unexpected opportunities. He is developing an 'Introduction to Robotics' course for the Great Courses, a company in Chantilly, Virginia, that sells DVD-based teaching materials. Long has also formed a research collaboration with Josh Bongard, a cognitive researcher at the University of Vermont in Burlington whom he met after Bongard reviewed his book for the magazine New Scientist.

Book publishing has always been a risky business. "The amount of work isn't proportional to the pay-off," says Laura Wood of Fine Print Literary Management in New York City. It is not about the money, Haskell emphasizes. "Irrepressible love of language and science," he says, "is the only good reason I can think of to set pen to paper."

Sarah Webb is a freelance writer based in Chattanooga, Tennessee.

\section{RELOCATION}

\section{International impact}

Scientists who move countries tend to publish in higher-impact journals than those who remain at home, a study finds (C. Franzoni et al. Econ. Lett. http://doi.org/p68; 2013). The authors asked about the relocation history of 14,299 researchers of all career stages in biology, chemistry, Earth and environmental sciences and materials science in 16 nations. Looking at papers published in 2009, the team found that scientists who were living in countries other than the ones they had been living in at age 18 published in journals with impact factors an average of 1.07 points higher than scientists who stayed put. Moving may help scientists to find work settings where they can maximize their potential, says co-author Chiara Franzoni, an economist at the Polytechnic University of Milan in Italy.

\section{DIVERSITY}

\section{Inequalities at work}

Women of colour comprised $5.7 \%$ of US science, technology, engineering and maths (STEM) academic faculty members with doctorates in 2010, a report says; white men made up 58\%. Accelerating Change for Women Faculty of Color in STEM adds that the low numbers and restricted advancement of minority women on STEM faculties limit innovation and role models. It notes that university leadership should value diversity, but women of colour must cut time spent on committee service and mentoring, learn how job duties count towards tenure and pay rises, and welcome help, says Barbara Gault, co-author of the report and vice-president of the non-profit Institute for Women's Policy Research in Washington DC.

\section{RECRUITMENT}

\section{Florida hiring push}

The University of Florida in Gainesville is recruiting 100 researchers in 16 fields including neurology, global health, plant genomics, metabolomics and drug discovery. The move is part of a strategy to become a leading research university, says spokesman Chris Moran. The institution has received US\$15 million in state funds, which it will match with privately raised money to create 107 endowed seats that could be occupied by new recruits or existing faculty members. The money will also support the construction of research facilities and other initiatives. 